\title{
JUSTYNA ŁOPACZYK
}

\author{
Wiesław Babik, Słowa kluczowe, Kraków: \\ Wydawnictwo Uniwersytetu Jagiellońskiego \\ 2010, ss. 241
}

W dobie rozwoju technologii cyfrowych, a tym samym rewolucji w dziedzinie informacji, narzędziem szczególnie pożądanym, służącym do budowania charakterystyk wyszukiwawczych i wyszukiwania dokumentów, jest - odkrywany na nowo - język słów kluczowych, oparty na indeksowaniu współrzędnym. Czy ten paranaturalny i ahierarchiczny język informacyjno-wyszukiwawczy w swojej odmianie nieklasycznej ustąpi miejsca swobodnym słowom kluczowym, tj. elementom języka naturalnego, dobrze znanym użytkownikom internetu? Te dwie odmiany języka informacyjno-wyszukiwawczego, poddane rzeczowej analizie autora, są wyraźnie obecne w omawianej książce.

O przyszłości języka słów kluczowych traktuje nowa, niezwykle ciekawa publikacja specjalisty w zakresie języków i systemów informacyjno-wyszukiwawczych, Wiesława Babika, dra hab. nauk humanistycznych w dziedzinie językoznawstwa, znawcy, którego rekomendować - myślę - nie trzeba. Książka Słowa kluczowe nie tylko jest głosem w dyskusji nad przyszłością wykorzystania słów kluczowych, ale stanowi przede wszystkim dogłębne i całościowe - pod względem zarówno teoretycznym, jak i historycznym - opracowanie dotyczące genezy, istoty, struktury oraz wykorzystania języka słów kluczowych w tradycyjnych i nowych systemach informacyjnych. Babik otrzymał za tę publikację Nagrodę im. Adama Łysakowskiego w kategorii prac o charakterze teoretycznym, metodologicznym, źródłowym. Celem publikacji jest - jak określa sam autor, który językami słów kluczowych zajmuje się od 1986 roku - „próba zdefiniowania tego języka [słów kluczowych - J.Ł.] poprzez ustalenie jego cech konstytutywnych, określających jego tożsamość i rolę w obecnym heterogenicznym sieciowym środowisku informacyjnym" (s. 10). Cel ten został w pełni osiągnięty. Publikacja - oprócz istotnych Metodologicznych 
aspektów rozważań nad słowami kluczowymi (s. 9-22), zakończenia: Od rozważań teoretycznych do praktyki (s. 205-216), wykazu literatury (s. 217-225), indeksów (s. 227-234) oraz aneksu z wykazem słowników słów kluczowych, spisu rysunków i streszczenia w języku angielskim (s. 235-241) - zawiera trzy części zasadnicze (dwie pierwsze bardziej teoretyczne, trzecią - źródłową): Słowa kluczowe w różnych kontekstach (s. 24-78), Słowo kluczowe jako jednostka leksykalna języka słów kluczowych (s. 79-120), Słowa kluczowe w systemach wyszukiwania informacji (s. 121-204).

W pierwszej części, metodologicznej i stanowiącej konieczną podstawę do zrozumienia treści zawartych w części drugiej, autor wyjaśnia, czym są słowa kluczowe i w jakich kontekstach się pojawiają. Kontekst funkcjonalny jest tylko jednym z wielu, a konteksty indeksowania i wyszukiwania informacji stanowią najważniejszy - doskonale ukazany przez autora obszar, w którym wykorzystuje się słowa klucze. Zapoznając czytelnika z terminem „słowo kluczowe”, Babik rozróżnia: po pierwsze - wyrażenia z zapytania informacyjnego, z tytułu lub z tekstu dokumentu, które służą do kodowania treści (język naturalny); po drugie - jednostki leksykalne języka słów kluczowych pochodzące z treści, kontrolowane (język paranaturalny). Omawia zastosowanie słów kluczowych w kodach HTML stron internetowych, w wyszukiwarkach internetowych, systemach hipertekstowych i hipermedialnych. Zwraca uwagę na pewną kompatybilność, zależność organizacji słów kluczowych od systemu poznawczego człowieka, ludzkich możliwości. Taka zależność - zdaniem autora - jest wręcz pożądana i możliwa dzięki wykorzystaniu tzw. modeli pamięci semantycznej, w których istotną rolę odgrywają sieci semantyczne. Babik, dokładny w swoich rozważaniach, powołuje się między innymi na model hierarchiczny opracowany przez Allana M. Collinsa i M. Rossa Quilliana (relacje hiperonimii i hiponimii, relacje kojarzeniowe struktur językowych, gniazda pojęciowe, semantyczne, leksykalne - por. s. 48-49) oraz model niehierarchiczny Allana M. Collinsa i Elizabeth F. Loftus (struktura pojęć przypomina sieć złożoną z węzłów oraz połączeń między nimi, tzw. ścieżek - por. s. 5); zwraca uwagę na relacje między wyodrębnionymi w pamięci pojęciami oraz na strukturę pamięci semantycznej widzianej przez pryzmat kategoryzacji. Efektem zależności i „zbiorem procesów pamięciowych” oraz „procesów produkcji i odbioru tekstów języka informacyjno-wyszukiwawczego" są słowniki mentalne (zob. s. 53), które dalej stanowią podstawę do tworzenia języka swobodnych słów kluczowych. Wychodząc od procesów, zachodzących w umyśle człowieka, a kończąc na budowaniu systemów informacyjno-wyszukiwawczych, autor podkreśla, że szczególnie ważne są: semantyczna organizacja leksykonu umysłowego i relacje paradygmatyczne między leksemami, kompatybilność 
kompetencji komunikacyjnej i językowej w budowaniu wiedzy językowej oraz właściwa analiza wiedzy językowej (werbalne odwzorowanie rzeczywistości) i pozajęzykowej (konceptualne odwzorowanie rzeczywistości). Część pierwszą zasadniczego zrębu publikacji zamyka porównanie na zasadzie wskazania różnic i podobieństw - definicji terminu jako jednostki leksykalnej, dalej pola semantycznego oraz relacji kojarzeniowych w języku naturalnym i w języku słów kluczowych, a także kwestie związane z tematem kompetencji językowej użytkowników języka słów kluczowych i struktury języka słów kluczowych, będącej efektem modelowania w języku naturalnym.

Część druga zatytułowaną Słowo kluczowe jako jednostka leksykalna, rozpoczynają dwa rozdziały poświęcone historii języka słów kluczowych (zob. s. 80-85). Autor nawiązuje do prototypu języka słów kluczowych, którym były indeksy słów kluczy (wykazy wyrazów głównych tytułu, konkordancje), a genezę powstania i rozwój omawianego języka informacyjno-wyszukiwawczego wiąże zarówno ze średniowiecznymi inwentarzami, jak i z XX-wiecznym indeksowaniem współrzędnym (kojarzeniowym) Mortimera Taubego, które cechuje się brakiem relacji paradygmatycznych między słowami; „,każde słowo kluczowe grupuje opisy dokumentów, w których charakterystykach wystąpiło" (s. 81). Jako narzędzie indeksowania współrzędnego Babik wymienia i krótko omawia pierwowzór języka słów kluczowych, tj. język unitermów (budowany metodą indukcyjna, $\mathrm{w}$ miarę indeksowania dokumentów z terminów nierozkładalnych, jednowyrazowych w dowolnej kolejności), dalej wspomina o systemie UNITERM (tworzony w wyniku rozbicia standardowych haseł przedmiotowych, przez klasyfikację na zestawy pojedynczych terminów) oraz o języku deskryptorowym (składa się z deskryptorów i askryptorów, jest tworzony metodą dedukcyjna, odgórnie), za którego twórcę uważa się Calvina Northrupa Mooersa. W rozdziale tym zajmuje się definicją i naturą języka słów kluczowych; zastanawiając się nad jego paranaturalnością (lub identycznością z językiem naturalnym w przypadku swobodnych słów kluczowych), dochodzi do wniosku, że o sztuczności bądź naturalności języka decyduje metoda jego budowy (por. s. 87-88). Zdaniem Babika język słów kluczowych jest przykładem języka sztucznego, powstałego przy użyciu metody dedukcyjnej, natomiast język swobodnych słów kluczowych - językiem naturalnym, utworzonym za pomocą metody indukcyjnej. W dalszej części rozdziału autor wylicza i charakteryzuje podstawowe i pochodne funkcje języka słów kluczowych oraz dokładnie omawia strukturę tego języka, analizując wymiar wertykalny (poziomy języka słów kluczowych) oraz wymiar horyzontalny (elementy języka słów kluczowych: słownictwo w systemie 
leksykalnym i słownikowym, semantyka języka słów kluczowych, reguły gramatyczne). Istotne dla całości zagadnienia, jakim są języki informacyjno-wyszukiwawcze, jest podział języków słów kluczowych (klasyczne i nieklasyczne) i ich związek z językiem naturalnym, a także usytuowanie klasycznego języka słów kluczowych w kontekście języków deskryptorowego i haseł przedmiotowych. Babik wylicza podobieństwa i różnice w organizacji wymienionych języków informacyjno-wyszukiwawczych. Dopełniając całości, warto jeszcze zwrócić uwagę na - wymienione przez autora - zalety i wady języków słów kluczowych. Do zalet zalicza między innymi: stosowanie języka naturalnego bądź paranaturalnego, swobodne indeksowanie współrzędne, otwartość i elastyczność we wprowadzaniu nowych pojęć; wśród wad wymienia: powstawanie szumu informacyjnego, niestabilność systemu i jego wieloznaczność (synonimia, homonimia) por. s. 113.

W rozdziale trzecim autor omawia zastosowanie języka słów kluczowych w praktyce, zwraca uwagę na tożsamość wykorzystanych języków oraz ich kierunki rozwoju. Przedstawia wyniki badań własnych i wnioski z przeprowadzonych analiz. Szczegółowo charakteryzuje zarówno słownictwo języka słów kluczy w systemach tradycyjnych, jak i słowa kluczowe $\mathrm{w}$ systemie WWW. Do pierwszej grupy zalicza: klasyczne słowniki słów kluczowych (słowniki jednojęzyczne w systemach SYNABA, CYTBIN, BOINTE, GOSPODARKA, BAZTECH) oraz słowniki nieklasyczne: słów kluczowych z systemami odesłań, z elementami fasetyzacji, słowniki słów kluczowych w układzie gniazdowym, wielojęzyczne słowniki słów kluczowych oraz słowa klucze w indeksach rzeczowych, systemach pełnotekstowych, katalogach bibliotecznych (OPAC), bibliotekach cyfrowych (s. 124-159). Autorska analiza dostarcza niezbędnych informacji również natury historycznej. Babik informuje czytelników o zadaniach systemów (np. SYNABA - zawiera dane na temat badań naukowych w Polsce; CYTBIN - dotyczy cytowań publikacji z zakresu informacji naukowej i bibliotekoznawstwa; BAZTECH - baza bibliograficzno-abstraktowa, która rejestruje opisy artykułów z polskich czasopism technicznych, periodyków z dziedziny nauk ścisłych i ochrony środowiska). Autor podkreśla specyfikę i różnice między słownikami klasycznych języków słów kluczowych a słownikami języków nieklasycznych, których cechę stanowi występowanie relacji paradygmatycznych między wyrazami. Charakteryzuje, co jest niezwykle istotne, stosowanie słów kluczy w skomputeryzowanych katalogach bibliotecznych, indeksach tworzonych automatycznie, indeksowaniu i wyszukiwaniu dokumentów, w tym również do opisu i wyszukiwania informacji graficznej oraz "w analizie i odkrywaniu zawartości dźwiękowych dokumentów audialnych" 
(s. 156), a także w internecie (klasyczny język słów kluczowych, wyodrębnionych na podstawie zasady literary warrant - s. 137). W tym ostatnim przypadku model indeksowania i wyszukiwania informacji należy nie do języka, ale do systemu. Taka perspektywa wykorzystania słów kluczy w zautomatyzowanym świecie współczesnej nauki pozwala autorowi na stwierdzenie, że przyszłość należy do klasycznych języków słów kluczowych. „Możliwości dostępu do informacji cyfrowej, jakie stwarza Internet, zwłaszcza dla jego nieprofesjonalnych użytkowników, skłaniają do rezygnacji z wyrafinowanych narzędzi wyszukiwawczych [...] na rzecz prostych narzędzi [...]. Takim lingwistycznym narzędziem wyszukiwania informacji są właśnie słowa kluczowe" (s. 201).

Słowa kluczowe to kompendium niezwykle potrzebne, wypełniające lukę w literaturze przedmiotu i - co ważne - pokazujące miejsce języka słów kluczowych oraz swobodnych słów kluczy w słownikach, indeksach rzeczowych, systemach pełnotekstowych, katalogach bibliotecznych (OPAC), bibliotekach cyfrowych czy - wreszcie jako rzecz nową - w wyszukiwarkach internetowych.

Istotne wydaje się kognitywne podejście autora do analizowanych badań, odwołanie się do psycholingwistyki, procesów pamięciowych, kompetencji językowej czy sposobu myślenia użytkowników, którzy w praktyce korzystają już nie tylko z języka kontrolowanych słów kluczowych, ale także ze słów kluczy zaczerpniętych z języka naturalnego (strony WWW, wyszukiwarki internetowe).

Autor posłużył się metodą analizy piśmiennictwa, w celach badawczych wykorzystał materiał źródłowy (omówił fragmenty wybranych zestawień słów kluczowych, m.in. systemu SYNABA, bazy danych CYTBIN, słowników słów kluczowych z różnych dziedzin), metodą porównawczą (porównanie języków słów kluczowych z językami haseł przedmiotowych i językami deskryptorowymi), metodą psychologiczną (obserwacja zachowań użytkownika); poddał analizie ewolucję omawianego języka informacyjno-wyszukiwawczego oraz szeroko omówił pragmatykę indeksowania i wyszukiwania za pomocą słów kluczowych.

Cechą, która zasługuje na podkreślenie, jest umiejętne odwoływanie się do źródeł, powoływanie się na definicje, sformułowane przez językoznawców i teoretyków w dziedzinie języków informacyjno-wyszukiwawczych, filozofów i psychologów - zarówno polskich, jak i obcych. Autor nie pozostawia czytelnika samemu sobie; wykorzystując rozbudowany system przypisów (por. s. 9, 11, 13, 25, 31, 34-35, 48, 49, 60, 61, 80, 96, 114-115, 137, 172, 183), daje odbiorcy szansę i możliwość, aby w sposób perfekcyjny mógł on zapoznać się z definicjami i dotrzeć do źródeł publikacji dotyczących tematu - polskich i obcojęzycznych - istotnych 
dla zrozumienia treści Słów kluczowych. Dodatkowo każdy z trzech działów głównych zawiera streszczenie prezentowanych $\mathrm{w}$ nim informacji, swoiste podsumowanie oddzielone gwiazdkami od treści głównej. Taka forma prezentacji materiału pozwala na dogłębną analizę tematu, sprawia, że praca staje się czytelna w odbiorze.

Wiesław Babik kieruje publikację do szerokiego grona odbiorców: specjalistów w dziedzinie języków informacyjno-wyszukiwawczych, dokumentalistów, bibliotekarzy, studentów i osób zainteresowanych językiem słów kluczowych, umiejętnie posługując się naukowym, specjalistycznym (ale - co warto podkreślić - w miarę przystępnym) językiem, który zachęca do lektury.

Publikacja Słowa kluczowe zasługuje na uznanie ze względu na całościowe ujęcie tematu, nowatorstwo treści i przejrzysty sposób prezentacji. Powinna zainteresować wszystkich, którzy w jakimkolwiek stopniu maja do czynienia z językami informacyjno-wyszukiwawczymi, nie tylko z językiem słów kluczowych w wydaniu klasycznym, ale - ze względu na liczne odwołania - z każdym z tych quasi-naturalnych języków, służących do porządkowania treści dokumentów w przestrzeni metainformacyjnej. 